\title{
THE IMPACT OF ESG FACTORS ON MARKET VALUE OF COMPANIES FROM TRAVEL AND TOURISM INDUSTRY
}

\author{
George H. IONESCU ${ }^{*}$, Daniela FIROIU ${ }^{2}$, \\ Ramona PIRVU ${ }^{3}$, Ruxandra Dana VILAG ${ }^{4}$ \\ 1,2,4Romanian-American University, Bucharest, 1B Expozitiei Blvd, \\ 1st district, Bucharest, 012101, Romania \\ ${ }^{3}$ University of Craiova 13 A. I. Cuza Street, Craiova, 200585, Romania
}

Received 11 September 2017; accepted 17 February 2019

\begin{abstract}
The aim of this paper is to investigate the relationship between environmental, social, and governance (ESG) factors and firm market value for the companies from travel and tourism industry and, in the same time, to investigates the question if the association between good ESG scores for travel and tourism companies and their market value can be used as a performance predictor. The impact of extra-financial ESG performance on market value of the companies was estimated using the modified version of the Ohlson (1995) model, based on a sample of 73 listed companies, worldwide distributed, during the 2010-2015 period. The overall results of this research are consistent with the value enhancing theory (as opposed with the shareholder expense theory). From the ESG factors, the governance factor seems to have the most important influence on the market value of the selected companies, regardless of the geographic region where they are located. Thus, our findings provide new insights into the influence of each ESG factor on the market value of the companies, providing a useful tool for stakeholders to measure economic impact but also for use as a predictor of economic performance.
\end{abstract}

Keywords: ESG factors, firm value, economic performance, responsible investing, travel and tourism industry.

JEL Classification: G12, G32, Q01.

This research did not receive any specific grant from funding agencies in the public, commercial, or not-for-profit sectors.

\section{Introduction}

Among researchers and practitioners there is a growing consensus that ESG factors have a significant impact on the company's market value. Initial research suggests that financial markets reward companies with a good ESG score, while a lower ESG score may be an indi-

*Corresponding author. E-mail: george.ionescu@profesor.rau.ro 
cator of higher risk, given that the company is managed less efficiently than other companies in the same industry.

In this paper, we investigate the impact of environmental, social and governance (ESG) factors on market value of companies from travel and tourism industry. However, it should be noted that because of the lack of standard definitions or valuation models, the empirical research studies use a wide variety of data in assessing the impact of ESG factors on the market value of companies and different approaches.

We decided to focus our research on travel and tourism industry companies with the aim of addressing a gap in existing relevant research, based on three main reasons. First, we consider that travel and tourism industry deserves attention due to its large size and high number of stakeholders. At global level, in 2017, the direct contribution of travel and tourism industry to GDP was US\$ 2.57 trillion (3.2\% of global GDP), with the forecast to rise by $4.0 \%$ in 2018 , and supported more than 118.45 million jobs (3.8\% of total employment). In terms of indirect contribution to GDP, in 2017 travel and tourism industry is generated US\$ 8.27 trillion (10.4\% of GDP) and supported over 313.22 million jobs (9.9\% of global employment). Recent past showed that this industry is growing at a faster rate than both the wider economy and other significant sectors such as automotive, financial services and health care (World Travel and Tourism Council [WTTC], 2018).

The second reason that supports our research is that ttourism not only creates jobs in the tertiary sector but also encourages the growth of the primary and secondary sector of the industry. The travel and tourism industry is characterized by a high value of the multiplier effect on the economy, based on its direct economic impact, but also on its significant indirect and induced impacts. The direct impact is generated by industries that deal directly with tourists (hotels, travel agents, airlines and other passenger transport services, leisure industries, restaurants and retail stores). The indirect contribution includes government spending for supporting tourism activity, capital investments by all industries directly involved in travel and tourism industry, and, ultimately, the supply-chain effect generated by direct purchases of domestic goods and services. The induced impact is based on the spending by those who are directly or indirectly employed by this industry (WTTC, 2018).

The third reason for focusing our research on travel and tourism industry is that the companies from this industry have one of the most profound impact over the environment, through the construction of general infrastructure such as roads and airports, and of tourism facilities, including resorts, hotels, restaurants, shops, golf courses and marinas. The negative impact can gradually destroy the environmental resources on which it depends, so all the stakeholders, especially investors, should pay more attention to these factors and take them into account before taking action in the market.

The awareness of ESG criteria's importance in creating value for both company and society, has led firms to strengthen their efforts regarding the integration of ESG criteria in their activities and in providing the necessary data (extra-financial data) required by socially responsible investors. The public report on ESG issues is a method by which companies demonstrate a commitment to transparency and proactive management approaches to address externalities. A number of researchers claim that good ESG performance is a predictor of management efficiency for a company, and the companies that perform well on ESG criteria 
is expected to be more attuned with the general conditions of the market, having lower production costs and more motivated and productive employees.

Comprehensive literature review indicates that the impact of ESG factors on market value of companies has been intensively discussed. However, the conclusions are far from being unequivocal as recent surveys of the literature shows (Margolis, Elfenbein, \& Walsh, 2009; Clark \& Viehs, 2014; Friede, Busch, \& Bassen, 2015). Some research papers failed to find any correlation between ESG performance and market value of the company (Brammer, Brooks, \& Pavelin, 2006) or have found a non-significant correlation between these factors and market value (McWilliams \& Sigel, 2000; Renneboog, Horst, \& Zhang, 2008a, 2008b; Horvathova, 2010). More recent research papers argue that the ESG activities could have a positive impact on market value of the companies, but it is difficult to isolate and measure a direct causal link between good environmental, social and corporate governance performance and the company's market value (Porter \& Kramer, 2011; Eccles, Ioannou, \& Serafeim, 2014; Cai \& He, 2014; Malik, 2015; Fatemi, Fooladi, \& Tehranian, 2015; Bajic \& Yurtoglu, 2016).

In recent years, ESG business reporting covers not only how each company addresses and deals with ESG topics, but also explains what concrete measures the company has taken to support global engagement and find solutions, as opposed to only management of impacts.

The United Nations (UN) General Assembly has approved the adoption of 2017 as the International Year of Sustainable Tourism for Development. This decision comes at a particularly important moment as the international community embraces the new Agenda 2030 and the Sustainable Development Goals (SDGs). Because SDGs are globally set up and have a very broad scope, they are complemented by the development of specific policies and regulations on key sustainability issues - notably the Paris Climate Change Agreement and the British Act on slavery modern human rights. Also, within the European Union, the 2014/95/ EU Directive requires public-interest entities (PIEs) with more than 500 employees to report environmental, social and employee material topics on a yearly basis and to include policy, risks and performance for reported topics.

Tourism is included as targets under three of the SDGs: SDG 8 (Promote inclusive and sustainable economic growth, employment and decent work for all), SDG 12 (Ensure sustainable consumption and production patterns), and SDG 14 (Conserve and sustainably use the oceans, seas and marine resources for sustainable development).

It is also considered that travel and tourism industry can also contribute indirectly to the achievement of another three SDGs: SDG 9 (Build resilient infrastructure, promote sustainable industrialization and foster innovation), SDG 10 (Reduce inequality within and among countries), and SDG 17 (Revitalize the global partnership for sustainable development).

This paper focuses on the question of whether the association between good ESG scores for travel and tourism companies and their market value can be used as a performance predictor. The tourism industry is rather complex, being fragmented into several different industries that, taken together, constitute what is commonly referred to as the travel and tourism industry (McIntosh \& Goeldner, 1990). It comprises components of other industries that is not exclusively providing for tourists (Power, 1996). Tourism industry's sectors include transportation (e.g., airlines, buses and automobiles), lodging, restaurants, the cruise industry, amusement parks and resorts, and general retail and merchandise stores (Johnson, 
1994). Included in the definition of the tourism industry is the associated development (e.g., tourist infrastructure) of tourist destinations, and tourist activities (Davis \& Cahill, 2000).

Giese, Lee, Melas, Nagy, and Nishikawa (2017) showed there are various ways to measure valuation levels, e.g., using fundamental valuation ratios such as book-to-price or book-toearnings, or by looking directly at stock price movements while controlling for the market and other factors.

The sample of this research study was represented by companies belonging to travel and tourism industry or having direct links with it, from different countries around the world, with individual ESG scores. This study is focused on different companies included in S\&P Global Broad Market Index Universe (BMI), based on 5859 company rated observations world-wide between 2010-2015.

Our main contribution to the literature is that we provide an insight for assessing the impact of environmental, social and governance factors on market value of companies from travel and tourism industry, addressing the information gap for this important industry. The results of this research could identify a correlation between ESG factors and market value of companies from travel and tourism industry. This study, along with the increasing number of other studies, will probably move the pressure over investors and company managers to merge environmental social governance criteria in their investments. New concepts are constantly evolving to describe sustainable investments, and ESG criteria could play an important role within this sustainable investment, especially for the companies in the travel and tourism industry, due to their relevant economic and environmental impact at a global level.

This paper is organized as follows: first, a literature review is presented regarding the environmental, social and corporate governance factors and their relevance for this research. Next, the research methodology is described. Then, the results of our study are explained, and, finally, we present a discussion and conclusion section, including some of the implications of the impact of ESG factors on market value of the companies from travel and tourism industry, as well as the limitations of this study, and we suggest future research directions.

\section{Literature review}

The question of how ESG factors affect a company's economic and financial performance, and ultimately its market value, has been the subject of long debates. According to the traditional neoclassical approach, investing in socially responsible aspects creates additional costs the companies (Palmer, Oates, \& Portey, 1995), and generally was perceived as a negative factor for economic performance, as the competiveness of the firm can be affected (Baumol \& Blackman, 1991). The underlying assumption is that the payoffs of investments in ESG related actions do not exceed the costs involved. Some recent research papers (Jacobs, Singhal, \& Subramanian, 2010; Fisher-Vanden \& Thorburn, 2011; Lyon, Lu, Shi, \& Yin, 2013) shows that companies reporting investments in ESG related activities or winning different green awards still experience negative abnormal returns, suggesting that the market participants are reluctant to invest based on this aspects.

More recently, however, different research papers argue in favor of the fact the investing in socially responsible activities may have a positive impact on market value of the company 
(Malik, 2015; Fatemi et al., 2015). According to Moon (2007), the complexity of corporate social responsibility over different organizations that impact differently the society and environment cannot be generalized, and the vast nature of pluralism in/of values of society makes it improbable to assert a universal vision of ethics much less corporate social responsibility. Corporate social responsibility can be studied as a multi-layered concept that varies on the concepts of economic, legal, ethical and philanthropic responsibilities.

A genuine social responsibility model needs to address four levels successively: economic, legal, ethical, and philanthropic. Inside the model, the fulfilment of economic responsibilities is made up of a reasonable return on investment, safe and adequately paying jobs and good quality at a fair price. The responsibility of the legal part of the model compels corporations to abide by the law codes as well as the moral codes of society. The ethical responsibility goes a step further than the legal responsibility in requiring that corporations act voluntarily in the way society expects them to. Lastly, the philanthropic responsibility deals with all issues that are yearned for by society but are not necessarily expected, for example charity donations (Carroll, 1991; Carroll \& Buchholtz, 2012). In the classical framework of stakeholder theory, the managers of a responsible company are obligated to take into consideration all stakeholders, namely, employees, non-government organizations and institutions, suppliers, when decisions concerning investments are made, not just shareholders (Freeman, 1984).

The discussion about corporate social responsibility has been undertaken within companies, among private and institutional investors, by academicians and in the media which has called more attention to the concept in the recent years. Big corporations have been increasing held accountable for their activities which has driven them to put out reports of corporate social responsibility and sustainability that give the public information of their subjection to social and environmental issues. Due to this attention and the ever increasing awareness and visible effects of social and environmental issues, private sector intuitions for example the Global Reporting Initiative and public policy makers for example the European Commission have put their minds together to discuss the issues of sustainability and corporate social responsibility with the goal of establishing best practice guidelines (Brown \& Fraser, 2006). As a result, global standards have been put forward as the best practice guidelines for sustainability and corporate social responsibility. These standards play a crucial role for corporations to identify their responsibilities and merge them into their management systems, production processes and supply chain (Waddock, Bodwell, \& Graves, 2002; Aguilera, Rupp, Williams, \& Ganapathi, 2007).

The explosion of interest in corporate governance is largely bound up with the recent spectacular increase in the concentration of shareholdings in large institutional investors' hands. Over the past three decades, holdings of shares by insurance companies and pension funds have grown considerably at the expense of holdings by individuals, in many developed economies. It is widely argued that this new concentration of shareholdings means that institutional investors now have both the ability and the incentive to monitor and discipline company manager; formerly, individual shareholders were thought to be too numerous and too widely dispersed to exert adequate corporate control, giving managers to, the potential to become entrenched and able to act in ways that maximized their own utility (Ping \& Cheng Wui Wing, 2011). The convergence of corporate social responsibility, which considers 
environmental and social performance, and corporate governance, gave birth to the pillars of environmental social governance (ESG).

Even by independently analyzing the influence and importance of each factor, we could find several relevant researches. The importance of the environmental factor is demonstrated in a research regarding the performance of listed companies at London Stock Exchange following the introduction of mandatory GHG emissions, Krüger (2015) concludes that "greater transparency increases corporate value, thanks to increased stock liquidity and lower information asymmetries". Radhouane, Nekhili, Nagati, and Paché (2018) investigates the implications for companies in reporting on environmental duties and they showed that both customers and shareholders perceive it favorably and tend to favor the companies with better environmental performance. In a similar research, Jacobs et al. (2010) found that the market is sensitive to announcements of environmental performance, with implications for the market value of companies.

The stakeholder theory supports a positive relationship between social and financial performance of a company. Orlitzky, Schmidt, and Rynes (2003) discussed how companies with good and sustainable relationship with the stakeholders could increase their level of competitiveness, which is transferred to the market value. Similarly, Hillman and Kleim (2001) showed that a good relationship with the key stakeholders could increase the intangible value of the companies. However, there are some researchers (Brammer et al., 2006) that suggest that not always could be spotted a positive relationship between social and financial performance, depending on the type of business.

Although there are different understandings and interpretations in the meaning of the word stakeholder, in most of the cases the characteristics set by Mitchell, Agle, and Wood (1997) are being just emphasized. Byrd, Cardenas, and Dregalla (2009) identifies four main basic stakeholders groups in tourism: government, entrepreneurs, tourists and local population. Also, we can add to these categories some specific influential groups (educational institutions, religious institutions), as well as the civil sector (associations and NGOs).

Between the problems that can occur in relation with the tourism stakeholders we can mention: distrust for the government or insufficient support of the government, inclusion of politics, too much administration or bureaucracy, exceeding influence of the key interest and influential groups, insufficient inclusion of individual interest groups, insufficient awareness on the need to participate, lack of guidance, wrongly defined priorities goals and conduction strategies, etc. (Krce Miočić, Razovič, \& i Klarin, 2016; Byrd et al., 2009).

In the last years, societal expectations have changed to the point that a business that simply maximises shareholder value or focuses on short-term earnings risks to disconnect from its customers and stakeholders over the long run. Companies are now expected to recognise their responsibility to the world and resources, and address them through the prism of business risk. Increasing the transparency, accountability, and sustainability of corporate processes is happening across the world (WTTC, 2017). Taking into account the cross-cutting nature of the issues identified, WTTC consolidated the "critical issues" into three core areas of relevance to the whole Travel \& Tourism sector: climate change, destination degradation and disruption. 
The impact of governance factor on market value of a company has been highlighted and documented by many scholars, research findings suggesting that a positive causal link can be identified between good corporate governance and the company's market value (Brown \& Caylor, 2006; Bebchuk \& Cohen, 2005; Gompers, Ishii, \& Metrick, 2003).

The vital importance of ESG indicators stays in capturing additional information on corporate performance not included in accounting data, as suggested by (Bassen \& Kovács, 2008). The authors define ESG as an extra-financial information about company's performance and challenges involving the ESG issues, which delivers additional relevant information and allows investors to have a more in-depth judgment on investment by enabling investors to better assess the risks and opportunities. Since ESG information is part of nonfinancial reporting and does not follow a standardized format as financial information does, ESG disclosure practices vary significantly (Elzahar, Hussainey, Mazzi, \& Tsalavoutas, 2015).

One of the main reason why the ESG criteria has been largely accepted in the theory of social responsible investing is that it leads to reduction in capital's cost and increasing in market value. The general perception is that any costs that may arise as a result of setting up a socially responsible structure of a company are offset by the costs of capital reduction. Another important reason it's the ability to enhance a company's image, thus reducing reputational risk. Looking at ESG from a marketing perspective, its adoption could provide costs and benefits identical as to those of an advertising campaign. A strong relationship has been established between a company's reputation and its social ratings (Waddock \& Graves, 1997). ESG factors has also been described as a strategic product that are sold by companies to their clients, that enhances revenues for companies which adopt it more quickly and readily, and less revenues for the other companies that take their time to take it on (Albuquerque, Durnev, \& Koskinen, 2015).

Another effect of ESG ratings for companies is that it provides extra-financial information in addition to the accounting measures that can deliver information about how well the company is managing its risks. With ever increasing fast impact of the media propagating news, both good and bad, the reputation issues of ESG could adversely affect a market's share price or lead to the downfall of a seemingly strong company. This implies that the effect of reduction of risk associated with ESG cannot be taken lightly.

Various research studies reveal a positive correlation between environmental, social and governance factors and non-financial performance predictors, including corporate reputation and brand equity (Hsu, 2012; Cahan, C. Chen, L. Chen, \& Nguyen, 2015), attracting and motivating employees (Bhattacharya, Sen, \& Korschun, 2008; Greening \& Turban, 2000), product and services differentiation (Boehe \& Cruz, 2010; Flammer, 2015), or customer satisfaction (Sen \& Bhattacharya, 2001; Walsh \& Bartikowski, 2013; Xie, 2014; Albuquerque et al., 2015).

On the other hand, the critics which have been put forward against environmental, social and governance criteria are advocating that the stakeholder theory can be opposed on the basis that the primary goal of a business is to maximize the wealth of the shareholders according to (Friedman, 1970) and any other goal putting the attention away from this one will result in the company being less effective. Some scholars believe that the shareholder's expectation is wealth maximization and the implementation of ESG criteria causes con- 
straints and should be done individually through channels like making donations or giving to charity (Zivin \& Small, 2005; A. Mackey, T. B. Mackey, \& Barney, 2007). Another strong argument advanced against ESG arises from studies of "sin stocks" which are stocks involved with alcohol, tobacco, weapons and the founding that their strong performance was the same as that of stocks reputed for socially responsible behavior. Some existing studies conclude that unlike what is commonly believed, the share price doesn't reflect socially responsible efforts (Statman \& Glushkov, 2009; Hong \& Kacperczyk, 2009).

It is noteworthy that Giese et al. (2017) examined how ESG information embedded within companies is transmitted to the equity market and they created three "transmission channels" within a standard discounted cash flow (DCF) model, namely the cash-flow channel, the idiosyncratic risk channel and the valuation channel. For the cash-flow channel, high ESG-rated companies are more competitive and can generate abnormal returns, leading to a higher profitability rate, for the idiosyncratic risk channel, high ESG-rated companies are better at managing company-specific business and therefore have a lower probability for operational risks, and for the valuation channel, high ESG-rated companies tend to have lower cost of capital which leads to higher valuations values in a DCF model framework.

All in all, integrating ESG criteria, for a company, has costs which are compensated through having more loyal and stable customers, lower cost of capital and having a good reputation. In the long run, the company eventually reduces its risks and enhances its performance because integrating ESG paints the true picture of the risks and opportunities that a company might face.

From the literature review we can identify three theoretical perspectives regarding the relationship between ESG factors and market value. One perspective, the traditional one, assumes that there is a negative correlation between ESG factors and market value, due to the additional costs implied by investing in ESG, which leads to a reduced profitability and market value. The classical profit-maximizing theory is violated by the resources reallocation from the company's investors to its stakeholders (Artiach, Lee, Nelson, \& Walker, 2010; Friedman, 1970).

The second perspective assumes there is no correlation between ESG factors and market value of the company, mainly because the level of investments in ESG is determined by using the cost-benefit analysis, and, accordingly, there is an equilibrium between the costs of ESG and the benefits from its provisions (Hassel \& Semenova, 2013). On the other hand, this neutral relation can be attributed to the fact that the financial market fails to include fully and efficiently the value of ESG factors in the pricing mechanism of the assets (Statman, 2000).

The third perspective assumes there is a positive correlation between ESG factors and market value, due to the better use of resources, improved relations with the shareholders, and better governance, all of them leading to a bigger market value of the company. In the same time, ESG practices could improve the relations with the stakeholders, bringing direct and indirect benefits to the company, thus influencing the increase in its value.

There is still a research gap regarding the impact od all the dimensions of environmental, social and governance factors on market value of companies. Most of the similar researches focus on aspects of corporate social responsibility including the environmental and social aspects and neglecting the governance aspect. For example, prior studies rely on the Kinder, 
Lydenberg and Domini database (KLD) to determine corporate social performance (McWilliams \& Siegel, 2001; Galema, Plantinga, \& Scholtens, 2008; Derwall, Koedijk, \& Ter Horst, 2010), but KLD scores can be considered not so reliable because they are incomplete regarding governance issues according to Galbreath (2013). We consider the following hypotheses:

Hypothesis 1: There is a positive correlation between the environmental score and the company's market value

Hypothesis 2: There is a positive correlation between the social score and the company's market value

Hypothesis 3: There is a positive correlation between the governance score and the company's market value

Taking into account the diversity of the results of the previous research, we want this study to contribute to the development of knowledge through the analysis made at the global level and at the level of three relevant economic regions, as well as provide stakeholders with the knowledge and tools needed to make the best decisions.

\section{Materials and method}

In this study, we decided to use ESG scores from RobecoSAM database, due to the broader information provided. We also relied on our choice and the fact that Bloomberg added RobecoSAM data as ESG function for sustainability investors.

This study is based on 5859 company rated observations world-wide, and focuses on different countries with ESG ratings. Despite the existence of some differences between countries in terms of cultural factors, macroeconomic patterns, regulatory backgrounds, or how ESG information is disclosed, the methodology of rating these companies and the criteria of selection to be listed on a reputable index like the Dow Jones Sustainability Indices (DJSI), represent a unified criterion to address these differences between countries.

The starting point for the sample selection is the starting universe which includes all companies listed on the S\&P Global Broad Market Index Universe (BMI), then from this we obtained the invited universe which includes 2500 companies by floated adjusted market capitalization in the BMI as well as current DJSI World components with above 500 million market capitalization. The assessed universe includes companies from travel and leisure industry that are rated listed on S\&P Global Broad Market Index Universe (BMI) between 2010 to 2015, with ESG scores based on information provided by RobecoSAM. The companies for which data was not available in terms of ESG scores or data as regards the variables in the model were excluded from the sample as they couldn't be useful in the development of the analysis.

After filtering the available data according to the chosen criteria, a number of 434 observations were kept for investigation, corresponding to a number of 73 ESG rated companies. Of the selected sample, $21.92 \%$ of companies originated in Europe, $31.51 \%$ in the United States and $46.57 \%$ in Asia. 
To investigate the impact of environmental, social and corporate governance factors on market value and sustainability of companies we chose a modified Ohlson (1995) model, because it can provide a theoretical and empirical framework for testing the hypothesis of influence of ESG factors on market value of the companies from travel and leisure industry.

From the previous researches, it is recognized that the market value of equity is an appropriate indicator for estimating the value of a company. Ohlson (1995) proposed to use a model for the valuation of listed companies in which the market value of equity is determined on the basis of company financial information plus other non-financial information that can be considered relevant. However, Ohlson did not specify which additional nonfinancial information could be used in the model. Thus, the model has begun to be widely used in research, using information on environmental, social and governmental factors as additional information (M. M. Miralles-Quiros, J. L. Miralles-Quirós, \& Valente Gonçalves, 2018; De Klerk, de Villiers, \& van Staden, 2015; Kaspereit \& Lopatta, 2013; Lourenço, Branco, Curto, \& Eugenio, 2012).

The Ohlson model demonstrates a long-run equilibrium relationship between stock price and the fundamental value of companies and, in the same time, has better ability to predict future stock price for different time horizons (Lee, Chen, \& Tsa, 2014).

The selected model is based on the hypothesis that the market expectations of future cash-flows are reflected in current earnings, the book value of equity, and other relevant non-accounting information. The empirical test focuses on whether the coefficient of nonfinancial ESG performance is significantly different from zero with the predicted sign. Rejecting the null hypothesis is interpreted as evidence that ESG performance is relevant and not totally unreliable (Barth, Beaver, \& Landsman, 2001). A positive coefficient on ESG factors influence denotes higher future abnormal earnings relative to current abnormal earnings. Value-relevance studies typically have implications on standard setters, policy makers and regulators, company managers, financial statement users, and financial and information intermediaries (Hassel \& Semenova, 2013).

For our research, the impact of extra-financial ESG performance on market value of the companies is estimated using the modified version of the Ohlson model (1995), as the following form:

where:

$$
\mathrm{dMTBV}=\beta_{0}+\beta_{1} \mathrm{ROA}+\beta_{2} \mathrm{ENV}+\beta_{3} \mathrm{SOC}+\beta_{4} \mathrm{GOV}+\varepsilon
$$

- MTBV is market to book value (Tobin's Q), computed as Market value/Book value;

- ROA or Return On Assets (Net Profit/Total Assets);

- ENV, SOC and GOV are the extra-financial Environmental, Social and Governance performance measured using third-party ratings from RobecoSAM scores database.

For the conducted analysis, the "distance" from 1 of the Market Value To Book Value (dMTBV) has been chosen as the dependent variable and the following independent variables - Environmental, Social and Governance factors, and Return On Assets (ROA) have been chosen as predictors.

The result shows how much the market value of a share differs form its book value. The market value is given by the price of selling of a specific share. This price should be a measurement of the value of the company, as well as investors' beliefs about the future of 
the company. The book value is a measurement of the financial position of the company, resulted from dividing Total Net Assets to the Number of shares. So MTBV would be one if this to measurements are equal, it will be under one if investors beliefs about the future of the companies are grim and it will be more than one if their beliefs are positive.

As argued by Lo and Lys (2000) and Brown, Lo, and Lys (1999), a lagged market value could act as a deflator for diminishing the scale effects. In our model we used dMTBV that is measuring the "distance" from one of MTBV, meaning dMTBV $=$ MTBV -1 . So if dMTBV is greater than zero investors have faith in company's future, if not they think that the company is going to face difficulties. A similar approach is used by Singh, Tabassum, Darwish, and Batsakis (2018) and Erickson and Whited (2012) to providing robustness towards to an unbalanced panel-data and to address specific autocorrelation.

There are several reasons we considered when we decided to work with panel data: it is possible to catch individual particularities, of the structure or in time; it offers more information about the individual variability; it will increase DOF (degree of freedom) and reduce the multicollinearity phenomena; it increase the efficiency of the econometric estimation. Among the limitations of this research, the use of panel data and time series relationships, raises an additional concern regarding the presence of fundamental changes in the internal and operational structure of companies that could lead to changes in the risk profile and financial relationships.

Another possible limitation of the study may be the level of wage costs for selected companies. Travel and tourism industry is characterized, in general, by a large number of low-skilled jobs, high staff turnover, few prospects for promotion, relatively low wages, and high seasonality of the employment demand (Casado-Diaz \& Simon, 2016; Sanchez-Ollero, Campos-Soria, \& Garcia-Pozo, 2014). However, in the case of the present research, selected companies are ranked among large or very large international companies, which means that they respect the principles of equal opportunities in terms of wages offered. Also, due to the large number of employees and high geographic dispersion of the companies analyzed, it can be assumed that salary differences can be considered to be offset to the level at which they do not represent a destabilizing factor of the analysis.

\section{Data and research design}

For this study, the selected sample is made up of 73 companies, and covers a geographic area of 17 countries around the world, grouped by country of origin in three regions: Europe, United States and Asia. Companies from United States and Japan account for slightly more than half of the whole sample ( 40 out of 73 ) and the rest of the countries share are all below $10 \%$ of the whole sample. Most of the other countries are evenly distributed below $5 \%$ share of the whole sample.

The time period of this study is six years, starting from 2010 to 2015 , which describes the post global financial crisis period. There are several reasons for using the selected period. First, in this time period the investors' attention extended to ESG factors due to the fact that there possibly is a positive correlation between creation of long-term value and ESG performance. Second, over this period of time, more and more companies have been invited to be rated and included in the Dow Jones Sustainability Index, and the inclusions and exclusions 
for the DJSI for this period are relatively small in numbers. Third, due to the global financial crisis, an increasingly number of studies on the importance and relevance of environmental, social and corporate governance factors in evaluating a company's responsible investing activities, with implications on market value and sustainability of the companies appeared.

Applying the Ohlson valuation model, Semenova, Hassel, and Nilsson (2010) has identified a positive correlation between environmental performance and market value of the companies. The evidence presented in the study indicates that the environmental and social performance ratings are relevant to investors, and concludes that the integration of the extrafinancial value approach into traditional investment analysis provides a richer picture on the long-term performance. In a similar research, Galbreath (2013) examined the extent to which ASX300 firms, over an eight-year period, are demonstrating ESG performance using data from a third-party, independent ESG ratings agency.

We decided to test our model at different levels. First, we test the working hypothesis at global level, using the entire population of selected companies. Secondly, we test the same hypothesis but for different regions (Europe, Asia and United States), taking into account the origins of the selected companies, based on the presumption that the regional investors' influence on the market is more important than the influence of investors from the other analyzed regions (Brown et al., 2004).

\subsection{Applying the research model for all the companies, at global level}

As a first step of our research we investigate the existing relationship between ESG factors and Return on Assets (ROA) as predictor variables, and Market to Book Value (MTBV) as outcome variable.

Table 1 provides descriptive statistics of the main variables used in this study. The table reports the mean, standard deviation, the minimum, and the maximum of the variables. The table shows that MTBV values range from 0.460 to 27.980 with mean value 3.90886; ROA data range from -0.097 to 0.220 with mean value 0.05579 ; environmental scores (ENV) range from 1.528 to 98.832 with mean value 38.94367; social scores (SOC) range from 14.159 to 90.242 with mean value 41.29155; and the governance scores (GOV) range from 12.814 to 91.240 with mean value 47.84104 . The data indicates that, on average, the ESG scores within our sample companies is below half the variation range, but with the governance scores being, on average, the highest. The significance of the general model was tested by ANOVA methodology (Table 2).

Table 1. Descriptive statistics (global) (source: own construction by using SPSS)

\begin{tabular}{|c|c|c|c|c|c|}
\hline & $\mathrm{N}$ & Minimum & Maximum & Mean & Std. Deviation \\
\hline MTBV & 434 & 0.460 & 27.980 & 3.90886 & 4.688884 \\
\hline ROA & 434 & -0.097 & 0.220 & 0.05579 & 0.043061 \\
\hline ENV & 434 & 1.528 & 98.832 & 38.94367 & 26.388556 \\
\hline SOC & 434 & 14.159 & 90.242 & 41.29155 & 19.359401 \\
\hline GOV & 434 & 12.814 & 91.240 & 47.84104 & 18.935434 \\
\hline
\end{tabular}


Table 2. Model summary and ANOVA (global) (source: own construction by using SPSS)

\begin{tabular}{|c|c|c|c|c|c|c|c|c|c|c|}
\hline \multicolumn{11}{|c|}{ Model Summary ${ }^{b}$} \\
\hline \multirow[b]{2}{*}{ Model } & \multirow[b]{2}{*}{$\mathrm{R}$} & \multirow[b]{2}{*}{ R Square } & \multirow[b]{2}{*}{$\begin{array}{l}\text { Adjusted } \\
\text { R Square }\end{array}$} & \multirow{2}{*}{$\begin{array}{c}\text { Std. Error } \\
\text { of the } \\
\text { Estimate }\end{array}$} & \multicolumn{5}{|c|}{ Change Statistics } & \multirow[b]{2}{*}{$\begin{array}{l}\text { Durbin- } \\
\text { Watson }\end{array}$} \\
\hline & & & & & $\begin{array}{c}\text { R } \\
\text { Square } \\
\text { Change }\end{array}$ & $\begin{array}{c}\mathrm{F} \\
\text { Change }\end{array}$ & df1 & df2 & $\begin{array}{c}\text { Sig. } \\
\text { F } \\
\text { Change }\end{array}$ & \\
\hline 1 & $0.600^{\mathrm{a}}$ & 0.360 & 0.354 & 3.768020 & 0.360 & 60.376 & 4 & 429 & 0.000 & 1.988 \\
\hline
\end{tabular}

a. Predictors: (Constant), GOV, ROA, ENV, SOC.

b. Dependent Variable: MTBV.

\begin{tabular}{|c|c|c|c|c|c|c|}
\hline \multicolumn{2}{|c|}{ Model $^{*}$} & $\begin{array}{c}\text { Sum } \\
\text { of Squares }\end{array}$ & df & Mean Square & F & Sig. \\
\hline \multirow{3}{*}{1} & Regression & 3428.847 & 4 & 857.212 & 60.376 & $0.000^{\mathrm{b}}$ \\
\cline { 2 - 8 } & Residual & 6090.931 & 429 & 14.198 & & \\
\cline { 2 - 8 } & Total & 9519.778 & 433 & & & \\
\hline
\end{tabular}

a. Dependent Variable: MTBV.

b. Predictors: (Constant), GOV, ROA, ENV, SOC.

\begin{tabular}{|c|c|c|c|c|c|c|c|c|}
\hline \multicolumn{9}{|c|}{ Coefficients $^{\mathrm{a}}$} \\
\hline & \multirow{2}{*}{ Model } & \multicolumn{2}{|c|}{$\begin{array}{c}\text { Unstandardized } \\
\text { Coefficients }\end{array}$} & \multirow{2}{*}{$\begin{array}{c}\begin{array}{c}\text { Standardized } \\
\text { Coefficients }\end{array} \\
\text { Beta }\end{array}$} & \multirow{2}{*}{$\mathrm{t}$} & \multirow{2}{*}{ Sig. } & \multicolumn{2}{|c|}{$\begin{array}{l}\text { 95.0\% Confidence } \\
\text { Interval for B }\end{array}$} \\
\hline & & B & $\begin{array}{l}\text { Std. } \\
\text { Error }\end{array}$ & & & & $\begin{array}{l}\text { Lower } \\
\text { Bound }\end{array}$ & $\begin{array}{l}\text { Upper } \\
\text { Bound }\end{array}$ \\
\hline \multirow{5}{*}{1} & (Constant) & 0.522 & 0.556 & & 0.938 & 0.034 & -0.571 & 1.616 \\
\hline & ROA & 62.070 & 4.339 & 0.570 & 14.306 & 0.000 & 53.542 & 70.597 \\
\hline & ENV & -0.007 & 0.016 & -0.039 & -0.437 & 0.036 & -0.038 & -0.024 \\
\hline & SOC & -0.086 & 0.025 & -0.354 & -3.369 & 0.001 & -0.136 & -0.036 \\
\hline & GOV & 0.078 & 0.022 & 0.315 & 3.622 & 0.000 & 0.036 & 0.120 \\
\hline
\end{tabular}

a. Dependent Variable: MTBV.

\begin{tabular}{|l|c|c|c|c|c|}
\hline \multicolumn{7}{|c|}{ Residuals Statistics $^{\mathrm{a}}$} \\
\hline & Minimum & Maximum & Mean & Std. Deviation & $\mathrm{N}$ \\
\hline Predicted Value & -4.16586 & 14.85751 & 3.90886 & 2.814039 & 434 \\
\hline Residual & -8.727507 & 21.772882 & 0.000000 & 3.750575 & 434 \\
\hline $\begin{array}{l}\text { Std. Predicted } \\
\text { Value }\end{array}$ & -2.869 & 3.891 & 0.000 & 1.000 & 434 \\
\hline Std. Residual & -2.316 & 5.778 & 0.000 & 0.995 & 434 \\
\hline
\end{tabular}

a. Dependent Variable: MTBV. 
The model of multiple linear regression that shows the correlation between dMTBV and its four predictors is:

$$
\mathrm{dMTBV}=0.52+62.07 \mathrm{ROA}-0.01 \mathrm{ENV}-0.09 \mathrm{SOC}+0.08 \mathrm{GOV} .
$$

Against our prediction, we found that environmental (ENV) and social (SOC) factors have an indirect or inverse influence over dMTBV, given by the negative sign of their coefficient. We can conclude that the analyzed data is correct if we take into consideration the correlation between coefficients and the confidence level rule. In the same time, as expected, the proportion ROA's influence over market value of the companies is considerable.

We will explore if the effect discovered is going to be the same, weaker or stronger by applying the same model for the three areas where the companies in our study are originating from Europe, Asia and United States regions. In the same time, we are trying to identify if there are any regional difference regarding the influence of the ESG scores on market value of the selected companies.

\subsection{Applying the model for European companies only}

Table 3 provides descriptive statistics of the main variables used for study the sub-set of companies originating in Europe. The table reports the mean, standard deviation, the minimum, and the maximum of the variables. The values for MTBV range from 0.530 to 7.360 with mean value 2.89258; ROA data range from -0.097 to 0.153 with mean value 0.05297 ; environmental scores (ENV) range from 7.831 to 98.832 with mean value 47.74964; social scores (SOC) range from 17.937 to 84.376 with mean value 46.91975 ; and the governance scores (GOV) range from 28.029 to 91.240 with mean value 52.98060. The data indicates that, on average, the environmental (ENV) and social (SOC) scores within our sample companies is below half the variation range, but with the notable distinction that governance (GOV) scores are above median value of the range. The results of ANOVA methodology are summarized in Table 4.

Table 3. Descriptive statistics (Europe) (source: own construction by using SPSS)

\begin{tabular}{|l|c|c|c|c|c|}
\hline & $\mathrm{N}$ & Minimum & Maximum & Mean & Std. Deviation \\
\hline MTBV & 97 & 0.530 & 7.360 & 2.89258 & 1.512181 \\
\hline ROA & 97 & -0.097 & 0.153 & 0.05297 & 0.038135 \\
\hline ENV & 97 & 7.831 & 98.832 & 47.74964 & 26.294234 \\
\hline SOC & 97 & 17.937 & 84.376 & 46.91975 & 18.452834 \\
\hline GOV & 97 & 28.029 & 91.240 & 52.98060 & 19.366255 \\
\hline
\end{tabular}

Table 4. Model summary and ANOVA (Europe) (source: own construction by using SPSS)

\begin{tabular}{|c|c|c|c|c|c|c|c|c|c|c|}
\hline \multicolumn{11}{|c|}{ Model Summaryb } \\
\hline \multirow{2}{*}{ Model } & \multirow{2}{*}{$\mathrm{R}$} & \multirow{2}{*}{$\begin{array}{c}\mathrm{R} \\
\text { Square }\end{array}$} & \multirow{2}{*}{$\begin{array}{l}\text { Adjusted } \\
\text { R Square }\end{array}$} & \multirow{2}{*}{$\begin{array}{l}\text { Std. Error } \\
\text { of the } \\
\text { Estimate }\end{array}$} & \multicolumn{5}{|c|}{ Change Statistics } & \multirow{2}{*}{$\begin{array}{l}\text { Durbin- } \\
\text { Watson }\end{array}$} \\
\hline & & & & & $\begin{array}{c}\text { R Square } \\
\text { Change }\end{array}$ & $\begin{array}{c}\mathrm{F} \\
\text { Change }\end{array}$ & df1 & df2 & $\begin{array}{l}\text { Sig. F } \\
\text { Change }\end{array}$ & \\
\hline 1 & $0.666^{\mathrm{a}}$ & 0.444 & 0.420 & 1.151842 & 0.444 & 18.365 & 4 & 92 & 0.000 & 1.784 \\
\hline
\end{tabular}

a. Predictors: (Constant), GOV, ROA, ENV, SOC.

b. Dependent Variable: MTBV. 
End of Table 4

\begin{tabular}{|c|l|c|c|c|c|c|}
\hline \multicolumn{2}{|c|}{ ANOVA $^{\mathrm{a}}$} \\
\hline \multirow{2}{*}{ Model } & & $\begin{array}{c}\text { Sum of } \\
\text { Squares }\end{array}$ & $\mathrm{df}$ & Mean Square & $\mathrm{F}$ & Sig. \\
\hline \multirow{3}{*}{1} & Regression & 97.462 & 4 & 24.366 & 18.365 & $0.000^{\mathrm{b}}$ \\
\cline { 2 - 8 } & Residual & 122.060 & 92 & 1.327 & & \\
\cline { 2 - 8 } & Total & 219.522 & 96 & & & \\
\hline
\end{tabular}

a. Dependent Variable: MTBV.

b. Predictors: (Constant), GOV, ROA, ENV, SOC.

\begin{tabular}{|c|c|c|c|c|c|c|c|c|}
\hline \multicolumn{9}{|c|}{ Coefficients $^{\mathrm{a}}$} \\
\hline & \multirow{2}{*}{ Model } & \multicolumn{2}{|c|}{$\begin{array}{l}\text { Unstandardized } \\
\text { Coefficients }\end{array}$} & \multirow{2}{*}{$\begin{array}{c}\begin{array}{c}\text { Standardized } \\
\text { Coefficients }\end{array} \\
\text { Beta }\end{array}$} & \multirow{2}{*}{$\mathrm{t}$} & \multirow{2}{*}{ Sig. } & \multicolumn{2}{|c|}{$\begin{array}{l}\text { 95.0\% Confidence } \\
\text { Interval for B }\end{array}$} \\
\hline & & B & Std. Error & & & & $\begin{array}{l}\text { Lower } \\
\text { Bound }\end{array}$ & $\begin{array}{l}\text { Upper } \\
\text { Bound }\end{array}$ \\
\hline \multirow{5}{*}{1} & (Constant) & 2.077 & 0.408 & & 5.088 & 0.000 & 1.266 & 2.888 \\
\hline & ROA & 25.750 & 3.285 & 0.649 & 7.838 & 0.000 & 19.225 & 32.275 \\
\hline & ENV & 0.029 & 0.011 & 0.508 & 2.640 & 0.010 & 0.007 & 0.051 \\
\hline & SOC & -0.045 & 0.020 & -0.544 & -2.275 & 0.025 & -0.084 & -0.006 \\
\hline & GOV & -0.016 & 0.014 & -0.037 & -0.208 & 0.036 & -0.024 & -0.010 \\
\hline
\end{tabular}

a. Dependent Variable: MTBV.

\begin{tabular}{|l|c|c|c|c|c|}
\hline \multicolumn{7}{|c|}{ Residuals Statistics $^{\mathrm{a}}$} \\
\hline & Minimum & Maximum & Mean & Std. Deviation & $\mathrm{N}$ \\
\hline Predicted Value & -0.67334 & 4.72645 & 2.89258 & 1.007587 & 97 \\
\hline Residual & -2.036656 & 2.905533 & 0.000000 & 1.127590 & 97 \\
\hline $\begin{array}{l}\text { Std. Predicted } \\
\text { Value }\end{array}$ & -3.539 & 1.820 & 0.000 & 1.000 & 97 \\
\hline Std. Residual & -1.768 & 2.523 & 0.000 & 0.979 & 97 \\
\hline
\end{tabular}

a. Dependent Variable: MTBV.

The model of multiple linear regression that shows the correlation between dMTBV (for Europe region) and its four predictors is:

$$
\mathrm{dMTBV}_{\text {Europe }}=2.08+25.76 \mathrm{ROA}+0.03 \mathrm{ENV}-0.05 \mathrm{SOC}-0.02 \mathrm{GOV} \text {. }
$$

For the European companies sub-set, notably is the changing of the coefficient environmental (ENV) scores and governance (GOV) scores from the global model. So on the European market it seems that the investors will be more influenced by this factors when judging the value of a share, and of a company, respectively. 


\subsection{Applying the model for Asian companies only}

Table 5 provides descriptive statistics of the main variables used for the Asian originating companies data sub-set. The MTBV values range from 0.460 to 26.760 with mean value 2.267; ROA data range from -0.060 to 0.220 with mean value 0.04313 ; environmental scores (ENV) range from 1.528 to 97.943 with mean value 31.08166; social scores (SOC) range from 15.366 to 90.242 with mean value 36.47600 ; and the governance scores (GOV) range from 12.814 to 91.193 with mean value 40.04256 . The data indicates that every score for ESG factors is below half the variation range for Asia region, with the lowest values among the analyzed regions. The results of the ANOVA methodology for the Asia model were presented in Table 6.

Table 5. Descriptive statistics (Asia) (source: own construction by using SPSS)

\begin{tabular}{|l|c|c|c|c|c|}
\hline & $\mathrm{N}$ & Minimum & Maximum & Mean & Std. Deviation \\
\hline MTBV & 198 & 0.460 & 26.760 & 2.26763 & 3.188818 \\
\hline ROA & 198 & -0.060 & 0.220 & 0.04313 & 0.038283 \\
\hline ENV & 198 & 1.528 & 97.943 & 31.08166 & 25.341848 \\
\hline SOC & 198 & 15.366 & 90.242 & 36.47600 & 19.209303 \\
\hline GOV & 198 & 12.814 & 91.193 & 40.04256 & 17.906428 \\
\hline
\end{tabular}

Table 6. Model summary and ANOVA (Asia) (source: own construction by using SPSS)

\begin{tabular}{|c|c|c|c|c|c|c|c|c|c|c|}
\hline \multicolumn{11}{|c|}{ Model Summaryb } \\
\hline \multirow[b]{2}{*}{ Model } & \multirow[b]{2}{*}{$\mathrm{R}$} & \multirow{2}{*}{$\begin{array}{c}\mathrm{R} \\
\text { Square }\end{array}$} & \multirow{2}{*}{$\begin{array}{l}\text { Adjusted } \\
\text { R Square }\end{array}$} & \multirow{2}{*}{$\begin{array}{l}\text { Std. Error } \\
\text { of the } \\
\text { Estimate }\end{array}$} & \multicolumn{5}{|c|}{ Change Statistics } & \multirow{2}{*}{$\begin{array}{l}\text { Durbin- } \\
\text { Watson }\end{array}$} \\
\hline & & & & & $\begin{array}{c}\mathrm{R} \\
\text { Square } \\
\text { Change }\end{array}$ & $\begin{array}{c}\mathrm{F} \\
\text { Change }\end{array}$ & df1 & $\mathrm{df} 2$ & $\begin{array}{l}\text { Sig. F } \\
\text { Change }\end{array}$ & \\
\hline 1 & $0.618^{\mathrm{a}}$ & 0.382 & 0.369 & 2.532627 & 0.382 & 29.827 & 4 & 193 & 0.000 & 1.985 \\
\hline
\end{tabular}

a. Predictors: (Constant), GOV, ROA, ENV, SOC.

b. Dependent Variable: MTBV.

\begin{tabular}{|c|c|c|c|c|c|c|}
\hline \multicolumn{7}{|c|}{ ANOVA $^{\mathrm{a}}$} \\
\hline Model & & $\begin{array}{l}\text { Sum of } \\
\text { Squares }\end{array}$ & $\mathrm{df}$ & Mean Square & $\mathrm{F}$ & Sig. \\
\hline \multirow{3}{*}{1} & Regression & 765.266 & 4 & 191.316 & 29.827 & $0.000^{\mathrm{b}}$ \\
\hline & Residual & 1237.940 & 193 & 6.414 & & \\
\hline & Total & 2003.206 & 197 & & & \\
\hline
\end{tabular}

a. Dependent Variable: MTBV.

b. Predictors: (Constant), GOV, ROA, ENV, SOC. 
End of Table 6

\begin{tabular}{|c|c|c|c|c|c|c|c|c|}
\hline \multicolumn{9}{|c|}{ Coefficients $^{\mathrm{a}}$} \\
\hline & \multirow{2}{*}{ Model } & \multicolumn{2}{|c|}{$\begin{array}{l}\text { Unstandardized } \\
\text { Coefficients }\end{array}$} & \multirow{2}{*}{$\begin{array}{c}\begin{array}{c}\text { Standardized } \\
\text { Coefficients }\end{array} \\
\text { Beta }\end{array}$} & \multirow{2}{*}{$\mathrm{t}$} & \multirow{2}{*}{ Sig. } & \multicolumn{2}{|c|}{$\begin{array}{l}\text { 95.0\% Confidence } \\
\text { Interval for B }\end{array}$} \\
\hline & & B & $\begin{array}{l}\text { Std. } \\
\text { Error }\end{array}$ & & & & $\begin{array}{l}\text { Lower } \\
\text { Bound }\end{array}$ & $\begin{array}{l}\text { Upper } \\
\text { Bound }\end{array}$ \\
\hline \multirow{5}{*}{1} & (Constant) & 0.917 & 0.514 & & 1.783 & 0.046 & 0.097 & 1.931 \\
\hline & ROA & 51.282 & 4.930 & 0.616 & 10.403 & 0.000 & 41.559 & 61.005 \\
\hline & ENV & 0.014 & 0.018 & 0.111 & 0.774 & 0.044 & 0.022 & 0.050 \\
\hline & SOC & -0.030 & 0.032 & -0.182 & -0.950 & 0.034 & -0.093 & -0.033 \\
\hline & GOV & -0.005 & 0.025 & -0.027 & -0.190 & 0.049 & -0.054 & -0.045 \\
\hline
\end{tabular}

a. Dependent Variable: MTBV.

\begin{tabular}{|l|c|c|c|c|c|}
\hline \multicolumn{7}{|c|}{ Residuals Statistics $^{\mathrm{a}}$} \\
\hline & Minimum & Maximum & Mean & Std. Deviation & $\mathrm{N}$ \\
\hline Predicted Value & -2.88863 & 11.46586 & 2.26763 & 1.970938 & 198 \\
\hline Residual & -5.335863 & 15.899028 & 0.000000 & 2.506783 & 198 \\
\hline Std. Predicted Value & -2.616 & 4.667 & 0.000 & 1.000 & 198 \\
\hline Std. Residual & -2.107 & 6.278 & 0.000 & 0.990 & 198 \\
\hline
\end{tabular}

a. Dependent Variable: MTBV.

The model of multiple linear regression that shows the correlation between dMTBV (for Asia region) and its four predictors is:

$$
\mathrm{dMTBV}_{\text {Asia }}=0.92+51.28 \mathrm{ROA}+0.01 \mathrm{ENV}-0.03 \mathrm{SOC}-0.01 \mathrm{GOV} \text {. }
$$

For the Asian companies sub-set, we note a sign change for the environment (ENV) and governance (GOV) coefficients from the global model, which means which means that the analyzed factors have an inverse influence on the outcome.

\subsection{Applying the model for United States companies only}

Table 7 provides descriptive statistics for the data use to explore variable's influence for US originating companies sub-set. The available data shows that MTBV values range from 0.970 to 27.980 with mean value 6.95594 ; ROA data range from -0.021 to 0.194 with mean value 0.07579; environmental scores (ENV) range from 7.292 to 86.725 with mean value 43.99763; social scores (SOC) range from 14.159 to 83.715 with mean value 44.22353 ; and the governance scores (GOV) range from 32.441 to 87.798 with mean value 55.36307. The data indicates that, on average, the environmental (ENV) and social (SOC) scores within our sample companies is below half the variation range, but with the notable distinction that governance (GOV) scores are above median value of the range. Table 8 summarizes the results obtained following the application of the ANAOVA methodology for the model that characterizes US companies. 
Table 7. Descriptive statistics (United States) (source: own construction by using SPSS)

\begin{tabular}{|l|c|c|c|c|c|}
\hline & $\mathrm{N}$ & Minimum & Maximum & Mean & Std. Deviation \\
\hline MTBV & 139 & 0.970 & 27.980 & 6.95594 & 6.239744 \\
\hline ROA & 139 & -0.021 & 0.194 & 0.07579 & 0.045561 \\
\hline ENV & 139 & 7.292 & 86.725 & 43.99763 & 24.865267 \\
\hline SOC & 139 & 14.159 & 83.715 & 44.22353 & 18.658309 \\
\hline GOV & 139 & 32.441 & 87.798 & 55.36307 & 15.606740 \\
\hline
\end{tabular}

Table 8. Model summary and ANOVA (United States) (source: own construction by using SPSS)

\begin{tabular}{|c|c|c|c|c|c|c|c|c|c|c|}
\hline \multicolumn{11}{|c|}{ Model Summary ${ }^{\mathrm{b}}$} \\
\hline \multirow{2}{*}{ Model } & \multirow{2}{*}{$\mathrm{R}$} & \multirow{2}{*}{$\begin{array}{c}\mathrm{R} \\
\text { Square }\end{array}$} & \multirow{2}{*}{$\begin{array}{l}\text { Adjusted } \\
\text { R Square }\end{array}$} & \multirow{2}{*}{$\begin{array}{l}\text { Std. Error } \\
\text { of the } \\
\text { Estimate }\end{array}$} & \multicolumn{5}{|c|}{ Change Statistics } & \multirow{2}{*}{$\begin{array}{l}\text { Durbin- } \\
\text { Watson }\end{array}$} \\
\hline & & & & & $\begin{array}{l}\text { R Square } \\
\text { Change }\end{array}$ & F Change & $\mathrm{df1}$ & df2 & $\begin{array}{l}\text { Sig. F } \\
\text { Change }\end{array}$ & \\
\hline 1 & $0.551^{\mathrm{a}}$ & 0.304 & 0.283 & 5.284434 & 0.304 & 14.601 & 4 & 134 & 0.000 & 1.830 \\
\hline
\end{tabular}

a. Predictors: (Constant), GOV, ROA, ENV, SOC.

b. Dependent Variable: MTBV.

\begin{tabular}{|c|l|c|c|c|c|c|}
\hline \multicolumn{2}{|c|}{ ANOVA $^{\mathrm{a}}$} \\
\hline \multirow{2}{*}{ Model } & & $\begin{array}{c}\text { Sum of } \\
\text { Squares }\end{array}$ & $\mathrm{df}$ & Mean Square & F & Sig. \\
\hline \multirow{3}{*}{1} & Regression & 1630.965 & 4 & 407.741 & 14.601 & $0.000^{\mathrm{b}}$ \\
\cline { 2 - 8 } & Residual & 3741.983 & 134 & 27.925 & & \\
\cline { 2 - 8 } & Total & 5372.948 & 138 & & & \\
\hline
\end{tabular}

a. Dependent Variable: MTBV.

b. Predictors: (Constant), GOV, ROA, ENV, SOC.

\begin{tabular}{|c|c|c|c|c|c|c|c|c|}
\hline \multicolumn{9}{|c|}{ Coefficients ${ }^{\mathrm{a}}$} \\
\hline & \multirow{2}{*}{ Model } & \multicolumn{2}{|c|}{$\begin{array}{l}\text { Unstandardized } \\
\text { Coefficients }\end{array}$} & \multirow{2}{*}{$\begin{array}{c}\begin{array}{c}\text { Standardized } \\
\text { Coefficients }\end{array} \\
\text { Beta }\end{array}$} & \multirow{2}{*}{$\mathrm{t}$} & \multirow{2}{*}{ Sig. } & \multicolumn{2}{|c|}{$\begin{array}{l}\text { 95.0\% Confidence } \\
\text { Interval for B }\end{array}$} \\
\hline & & B & $\begin{array}{l}\text { Std. } \\
\text { Error }\end{array}$ & & & & $\begin{array}{l}\text { Lower } \\
\text { Bound }\end{array}$ & $\begin{array}{l}\text { Upper } \\
\text { Bound }\end{array}$ \\
\hline \multirow{5}{*}{1} & (Constant) & 3.837 & 2.046 & & 1.875 & 0.043 & 0.210 & 7.883 \\
\hline & ROA & 69.053 & 10.475 & 0.504 & 6.592 & 0.000 & 48.336 & 89.770 \\
\hline & ENV & -0.055 & 0.035 & -0.219 & -1.558 & 0.022 & -0.125 & -0.015 \\
\hline & SOC & -0.050 & 0.058 & -0.151 & -0.878 & 0.038 & -0.164 & -0.063 \\
\hline & GOV & 0.046 & 0.067 & 0.115 & 0.685 & 0.049 & 0.086 & 0.178 \\
\hline
\end{tabular}

a. Dependent Variable: MTBV. 
End of Table 8

\begin{tabular}{|l|c|c|c|c|c|}
\hline \multicolumn{7}{|c|}{ Residuals Statistics $^{\mathrm{a}}$} \\
\hline & Minimum & Maximum & Mean & Std. Deviation & $\mathrm{N}$ \\
\hline Predicted Value & -1.81017 & 16.74557 & 6.95594 & 3.437817 & 139 \\
\hline Residual & -9.852506 & 19.935839 & 0.000000 & 5.207285 & 139 \\
\hline Std. Predicted Value & -2.550 & 2.848 & 0.000 & 1.000 & 139 \\
\hline Std. Residual & -1.864 & 3.773 & 0.000 & 0.985 & 139 \\
\hline
\end{tabular}

a. Dependent Variable: MTBV.

The model of multiple linear regression that shows the correlation between dMTBV (for United States) and its four predictors is:

$$
\mathrm{dMTBV}_{\mathrm{US}}=3.84+69.05 \mathrm{ROA}-0.06 \mathrm{ENV}-0.05 \mathrm{SOC}+0.05 \mathrm{GOV} \text {. }
$$

In terms of the model used to characterize the influence of ESG factors on the market value of the US originating companies, the coefficients have almost the same influence as the global model.

\section{Empirical results and discussion}

Once we analyzed the evolution of the variables and identified a number of existing influences between return on assets and ESG factors on market value of the listed companies' shares, we can first draw attention to the environmental values of the recorded ESG scores.

Thus, with regard to the descriptive statistics of recorded environmental scores, it can be noticed that the lowest scores (nominal and mean) were found in the sub-set data specific to Asian originating companies. Within these data is the lowest recorded value for all the companies included in our research (1.528) and the lowest mean score among all analyzed regions (31.08166). It seems that Asian stakeholders tend to attribute the least importance to ESG factors in their activity, since the factor's scores are at the lowest level between the analyzed regions. A possible explanation could come from the existing regulatory framework in the region, in terms of environmental factors, which do not provide sufficient incentives to justify the related investments, or does not provides significant sanctions for non-compliance.

As opposed to Asian based companies, the environmental score for the originating European companies is at the other extreme of the scale, with the highest values being recorded (absolute and average) between regions. Also, the lowest ENV score (7.831) was recorded for the companies in the Europe region, but also the highest value (98.832) of all the scores of the companies analyzed. As is well known, the existing environmental related framework at EU level provides a multitude of obligations for companies, and stakeholders are very aware of the importance of complying with these provisions. For this reason, research suggests that the management of companies in Europe region attaches great importance to environmental protection provisions, investors appreciate it consistently, which is also reflected in the evolution of market value. 
For US companies, the scores for environmental factor are higher than the average calculated for all surveyed companies, with the mention that the lowest score in this region (7.292) is much higher than the score registered by Asian companies and close to that registered by European companies. It is likely that the similarities between the EU and the USA in terms of the environmental regulatory framework will have the same effects on how stakeholders pay attention to these criteria.

However, it is worth pointing out in this case that, based on the model that quantifies the influence of ROA and ESG factors on US companies' market value, investors seem to penalize in a way the companies' initiatives related to the environment, through the negative correlation between ENV and MTBV value. These observations can be justified by the fact that the investments in the environment protection can prove to be costly for the company, which leads to the decrease of the profitability and implicitly the decrease of its market value.

This findings related to influence of environmental score on market value of companies from travel and tourism industry (Hypothesis 1) are mixed, with a higher and positive influence in Europe region, a positive but weak influence for Asian companies' market value, and a higher but negative influence for US companies. We can conclude that this findings are in line with the existing similar findings (Hassel, Nilsson, \& Nyquist, 2005; Moneva \& Cuellar, 2009; Artiach et al., 2010).

Regarding the influence of the social (SOC) factor on the market value of the companies from travel and tourism industry (Hypothesis 2), based on available data we found an unanimously negative relationship for the entire universe analyzed, but with different degrees of importance from one region to another. Thus, for companies originating in the Europe region, the mean score of the social factor is the best between the regions. It is noteworthy, however, that these companies have the highest mean score of all analyzed regions (46.91975) and also record the highest minimum score among all analyzed companies (17.937). It is very likely that a possible explanation for these results arise from the existing framework at the level of the European Union in terms of promoting social initiatives, and thus encouraging their appreciation. Stakeholders are aware of this and the companies are involved in community-based activities.

As for the companies originating in Asia region, as for the (ENV) score, companies located in this region record the lowest average value (36.47600) of the three analyzed regions, but paradoxically also display the highest individual value among all the analyzed companies (90.242). These results may be obtained in the light of the changes that have been made over recent years among companies in the region with regard to CSR activities. As Welford (2004) discussed, in the Asian companies there is a lower commitment to freedom of association and promotion of staff development and vocational education, but also the priorities for CRS initiatives vary according to the countries' norms, values and economic development.

The social factor score for US originating companies is found somewhere in the middle of the hierarchy, the mean score is situated above the average of all analyzed companies, below European companies and above Asian companies. However, in this case, the US companies record the lowest value for individual social factor score from all the companies included in this research, as well as the lowest individual maximum score. 
As a conclusion regarding the influence of the social factor (SOC) on the market value of the analyzed companies, we can state that the investors seem to dislike the social initiatives from the financial point of view, penalizing somehow the involvement of the companies in this direction. For the companies in all three analyzed regions there was a relationship of inverse proportionality between the social factor score and the market value. The results of this research are consistent with those obtained by a number of researchers, that consider that investing in CSR activities as a cost that is not recovered through direct or indirect benefits and the share price doesn't reflect socially responsible efforts (Statman \& Glushkov, 2009; Hong \& Kacperczyk, 2009), or the implementation of ESG criteria causes constraints (Zivin \& Small, 2005; Mackey et al. 2007). Moreover, as Liu and Zhang (2017) debates, corporate value will be lowered due to undertaking social responsibility; however, in the long run, good social responsibility information disclosure is helpful in enhancing corporate reputation and realizing sustainable development of enterprises.

Analyzing the influence of the governance factor (GOV) on the market value of companies from travel and tourism industry (Hypothesis 3), can not draw a universal conclusion, since the results of present research are mixed. Even if the general model used for all the companies at global level emphasizes the existence of a direct causality relationship, the analysis of the companies from the three selected regions shows a different distribution of the results. Thus, for the companies from the Europe region, the mean score (52.98060) for governance factor is above the average for all analyzed companies, along with the highest individual maximum value (91.240).

In the case of companies originating in the Asia region, and this time it records the lowest mean value of the governance score (40.04256), which is below the average value recorded for the whole target group analyzed. Also, at the level of this region, the lowest individual value of the (GOV) score is recorded among all the analyzed companies (12.814). These results are probably due to the fact that the application of the insights of corporate governance recommendations is uneven across the different countries of the region, recording significant variations, as with the social factor influence. These findings are consistent with the results obtained by the empirical evidence that shows no statistically significant relation between market valuation and corporate governance practice (Cheung, Jiang, Limpaphayom, \& Lu, 2008).

For companies originating in the US region, there is an increase in the importance of the governance factor score, both on the part of investors and stakeholders. Thus, companies in this region record the highest mean score of the (GOV) factor (55.36307), along with the highest individual value recorded among all companies analyzed (32.441). Moreover, at the level of the model that characterizes the influence of ESG factors on market value for companies in the US region, can be identified the existence of a relationship of direct proportionality between the score of the governance factor and the value of the company.

As a conclusion regarding the influence of the governance factor on the market value of companies from travel and tourism industry, based on this research we can state that the results obtained are mixed. On the one hand, leading the analysis at all selected companies, we can identify the existence of a positive and direct relationship between selected variables. By concentrating the analysis at the level of the regions, the results are not kept as clear, the 
relation of direct proportionality being maintained only for the companies originating from the US. For the other regions, the influence of the (GOV) factor is observed to be inversely proportional, with a rather weak link, being consistent with the previous studies (McWilliams \& Sigel, 2000; Horvathova, 2010). Similar research showed that voluntary and market corporate governance mechanisms have less effect when a country's governance system is weak (Claessens \& Yurtoglu, 2013).

The findings are, in general, consistent with the literature and are partially confirmed by the findings of Semenova et al. (2010), or Shank, Manullang, and Hill (2005). A relative weak influence of ESG performance indicates that stock markets have not fully recognized extrafinancial performance as a quantifiable intangible asset for companies from travel and tourism industry. From the ESG factors, the Governance factor seem to have the most important influence on the market value of the companies, which is consistent with findings of Bubbico, Giorgino, and Monda (2012) or Wang (2015). All these aspects translate into benefits for investors who become able to make their investments with greater awareness and reduced risk.

The implications for companies, managers and stakeholders are varied. There appears to be a series of behavioral barriers to the integration of ESG factors, many stakeholders consider that ESG investments largely involve changing mental models rather than adapting financial models to capture the influences of these factors. Eccles et al. (2014) suggest that there is a negative relationship between a firm's ESG performance and its market value and they argue that the market "will punish such activity" and will only reward companies that prioritize the most material ESG factors and come up with innovative approaches to address them.

The advantage of knowing the model by which investors incorporate the influence of ESG factors in determining the market value of the companies at different regional levels, enables managers to adapt their decisions so that they can take informed decisions about their activities and various initiatives at environmental, social and governance level. It is very important for managers to know the existing conditions, both in terms of barriers and the benefits they can bring to the company and the stakeholders using ESG disclosure.

It can be argued that on the basis of stakeholder theory (Freeman, 1984) it can be said that some benefits can be identified for firms to improve their ESG scores, given that this direction of action could bring increased financial and economic performance, with direct implications in market value increase. However, analyzing the results of this study, we can say that the link between ESG factors and the market value of companies is not totally understood and not fully recognized by the market participants.

The results may also be of interest to the management of companies that may wish to focus on development of one or more ESG factors so that they can achieve superior performance and, implicitly, have a higher market value that their competition. The results also show importance for public policy makers that could develop a series of concrete initiatives based on how ESG factors are perceived by stakeholders and reflected in the market value of companies.

Giese et al. (2017) have shown how ESG has affected the valuation and performance of companies, both through their systematic risk profile (lower costs of capital and higher valu- 
ations) and their idiosyncratic risk profile (higher profitability and lower exposures to tail risk). Thus, the transmission from ESG characteristics to financial value is a multi-channel process, as opposed to factor investing where the transmission mechanism is typically simpler and one dimensional.

In the same time, Giese, Lee, Melas, Nagy, and Nishikawa (2018) demonstrated that autocorrelation can impact the turnover created by ESG momentum in rules-based portfolio construction methodologies and have found a slight negative degree of auto-correlation between the tested companies data. This means that companies whose ESG scores have improved over one-year tended to see their score reverse the next year, i.e., there was no inertia but some degree of reversal in ESG score changes over time.

It should also be mentioned that Aouadi and Marsat (2018) have found that market value is highly correlated in absolute numbers to firm characteristics such as size, ROA, and sales growth, demonstrating that higher corporate social performance score has an impact on market value only for those companies which are larger, perform better, located in countries with greater press freedom, more searched on the Internet, more followed by analysts, and have an improved corporate social reputation.

It is worth noting that public policies are the main pillar of government activity, and in this context the role of government institutions is undeniable. With economic, social, cultural and environmental relevance, public tourism policies, and especially its sustainable development, are closely linked to the legislation in force, to the macro-environment factors, to the level of development of tourism at the level local and regional, with the opening of the local population to tourism, but also with all the advantages and negative effects generated by the tourism activities.

The major differences in the tourist regions and the countries involved in the responsible tourist activity (in terms of tourism's contribution to GDP, the population employed in tourism, export and import of tourism, etc.) generate differences also from the perspective of the economic performances obtained by analyzed companies. Thus, we can appreciate in the present context the existence of a direct link between the performing and sustainable public policies and the performance of the countries and companies that have emphasized the implementation of the new concept of economic activity development in correlation with the ESG factors, pursuing the Sustainable Development Goals as stated in the 2030 Agenda.

Lately, it has become increasingly visible that reporting on the implementation of ESG policy at the level of companies generate a much better visibility of companies on the market, constituting an efficient communication channel with the stakeholders and investors, influencing medium and long term performance.

Public reports on ESG factors generate responsibilities for local governments that can impose and verify, through transparent methods, the implementation and evaluation of specific policy rules using the legislative system and the master plans. Consequently, we can state that public policies directly influence how companies are concerned about implementing measures that favor ESG factors and, implicitly, influence their economic performance and market value. 


\section{Conclusions}

The aim of this study was to investigate the impact of environmental, social and corporate governance on market value of companies from travel and tourism industry. Overall, the empirical evidence supports an association between ESG performance and market value of the companies. We find different distinctions between the Environmental, Social and Governance component influences, and we can conclude that investors have started to integrate extra-financial performance into their investment decisions.

Starting from the main objective of the conducted study, four result variables have been defined: Return on Assets (ROA), Environmental (ENV), Social (SOC) and Governance (GOV) factors. The model has been applied at global and three regional levels (Europe, Asia and Unites States), taking into consideration the origins of the selected companies.

For the environmental factor's influence (Hypothesis 1), the results of research shows the existence of a weak link between the score of the factor and the market value, except for the US originating companies where the influence is stronger but negative. Considering that the selected companies belongs to the travel and tourism industry, it was expected to have a more consistent influence of the environmental factor on the value of the companies, and it was supposed that investors would be more receptive to the initiatives of the companies related to environmental issues. However, it seems that the financial implications prevail, as investors are considering the costs associated with environmental initiatives as not having a clear benefit for the analyzed companies.

Another approach to the results of this research regarding the impact of environmental reporting on the company's market value might be that because the tourism industry is a sensitive industry on environmental issues, the stakeholders are especially concerned about environmental practices but that these are already reflected in the share prices, which would be similar to the findings of Miralles-Quirós et al. (2018). The stakeholders should pay more attention to the direct and indirect impact that travel and tourism industry companies have on the environment, and consequently to evaluate more carefully the environment scores.

As far as the influence of the social factor is concerned (Hypothesis 2), the results obtained from this research are towards all in the same direction, i.e. all investments in social initiatives are seen as costs for the company, with their value exceeding the obtained benefits. Investors tend to penalize these initiatives, so for all the models used to identify both global influences and regional influences, the obtained results were similar, with the influence of the social factor on the market value of the companies being negative. Although the costs associated with social responsibility information disclosure are not beneficial for the shortterm economic performance of a company (Liu \& Zang, 2017), these efforts can provide long-term benefits by creating a better image of the company and facilitating communication between stakeholders, which can be a solid argument for attracting more attention from the stakeholders to assess this factor.

The results regarding the influence of the governance factor on the market value of the analyzed companies (Hypothesis 3) also showed some inconsistency in this research. At the level of the general model, a positive influence of the governance score on the market value could be identified, which was also true in the case of US-based companies. On the other hand, the influence of the governance factor on market value proved to be negative for com- 
panies originating in Europe and Asia regions, but with a slightly lower intensity than the rest of the analyzed companies.

An important point to be made is the fact that there are significant differences between the existing tourist regions at global level and the representative countries on the international tourism market (Asia Pacific, Europe, America, Middle East, Africa). Thus, in emerging markets, increases in reporting on the implementation of sustainable policies (India, Indonesia, Malaysia, South Africa) can be observed. This aspect supports the expansion of the corporate responsibility concept and the segments of other markets, while Europe and America are still at a high level of reporting.

We could say that there is a direct correlation between public policies, the implementation of company-specific ESG factors and the country-specific tourism development policy. In fact, the importance of tourism in both developed and developing countries can be understood in terms of concrete steps, implicit in terms of responding to the sustainable development of tourism.

It is noteworthy that for developing countries, the government and the private sector have a central role to play in setting policy and encouraging the development of tourism. In developing countries national tourism policies are usually state-owned, while in developed countries, entrepreneurs often dominate the formation and adoption of policies. In most developing countries, due to the small size of the private sector and the lack of funds, the government necessarily takes on the role of entrepreneur, and thus giving it quite often the sole responsibility for formulating and apply tourism policies.

This study is subject to some limitations, being based on a relatively small number of selected companies. Certainly, in the coming years, a growing number of companies will become aware of the importance of ESG factors on the market value of the company, and the investors will become more aware of taking into consideration their perceptions on how companies are governed and how companies handle environmental and social issues. Interesting conclusions can be drawn from this paper, although it is not free from external validity problems caused by data restrictions and a coarse level of analysis. In addition, potential unobserved factors may influence the level of controversies which in turn may also affect the relationship between ESG factors and market value of the companies.

Our research contributes to a better understanding of the integration of ESG influences on the market value of companies from travel and tourism industry while also provides a critical insight into the differences between stakeholder perception of these factors' influences at regional level. Even if the presented results also show that the market does not significantly value the three ESG pillars, the research may distinguish certain global and regional peculiarities that are suitable for consideration by investors and analysts when making their investment decisions, or by managers when adopting and implementing CSR strategies in regards with the stakeholders' expectations.

\section{References}

Aguilera, R. V., Rupp, D. E., Williams, C. A., \& Ganapathi, J. (2007). Putting the s back in corporate social responsibility: A multilevel theory of social change in organizations. Academy of Management Review, 32(3), 836-863. https://doi.org/10.5465/amr.2007.25275678 
Albuquerque, R. A., Durnev, A., \& Koskinen, Y. (2015). Corporate social responsibility and firm risk: Theory and empirical evidence. https://doi.org/10.2139/ssrn.1961971

Aouadi, A., \& Marsat, S. (2018). Do ESG controversies matter for firm value? Evidence from international data. Journal of Business Ethics, 151(4), 1027-1047. https://doi.org/10.1007/s10551-016-3213-8

Artiach, T., Lee, D., Nelson, D., \& Walker, J. (2010). The determinants of corporate sustainability performance. Accounting and Finance, 50(1), 31-51. https://doi.org/10.1111/j.1467-629X.2009.00315.x

Bajic, S., \& Yurtoglu, B. B. (2016). CSR, market value, and profitability: International evidence. https://doi.org/10.2139/ssrn.2848099

Barth, M. E., Beaver, W. H., \& Landsman, W. R. (2001). The relevance of the value relevance literature for financial accounting standard setting: another view. Journal of Accounting and Economics, 31(13), 77-104. https://doi.org/10.1016/S0165-4101(01)00019-2

Bassen, A., \& Kovács, A. M. M. (2008). Environmental, social and governance key performance indicators from a capital market perspective. Zeitschrift für Wirtschafts- und Unternehmensethik, 9(2), 182-192. https://doi.org/10.5771/1439-880X-2008-2-182

Baumol, W. J., \& Blackman, S. A. B. (1991). Perfect markets and easy virtue: Business ethics and the invisible hand. USA: B. Blackwell.

Bebchuk, L. A., \& Cohen, A. (2005). The costs of entrenched boards. Journal of financial Economics, 78(2), 409-433. https://doi.org/10.1016/j.jineco.2004.12.006

Bhattacharya, C. B., Sen, S., \& Korschun, D. (2008). Using corporate social responsibility to win the war for talent. MIT Sloan Management Review, 49, 37-44.

Boehe, D., \& Cruz, L. B. (2010). Corporate social responsibility, product differentiation strategy and export performance. Journal of Business Ethics, 91(Suppl 2), 325-346.

https://doi.org/10.1007/s10551-010-0613-z

Brammer, S., Brooks, C., \& Pavelin, S. (2006). Corporate social performance and stock returns: UK evidence from disaggregate measures. Financial Management, 35(3), 97-116. https://doi.org/10.1111/j.1755-053X.2006.tb00149.x

Brown, J., \& Fraser, M. (2006). Approaches and perspectives in social and environmental accounting: An overview of the conceptual landscape. Business Strategy and the Environment, 15(2), 103-117. https://doi.org/10.1002/bse.452

Brown, J. R., Ivkovic, Z., Smith, P., \& Weisbenner, S. (2004). The geography of stock market participation: The influence of communities and local firms (NBER Working Papers 10235). https://doi.org/10.3386/w10235

Brown, L., \& Caylor, M. (2006). Corporate governance and firm valuation. Journal of Accounting and Public Policy, 25(4), 409-434. https://doi.org/10.1016/j.jaccpubpol.2006.05.005

Brown, S. J., Lo, K., \& Lys, T. (1999). Use of R2 in accounting research: Measuring changes in value relevance over the last four decades. Journal of Accounting and Economics, 28(2), 83-115. https://doi.org/10.1016/S0165-4101(99)00023-3

Bubbico, R., Giorgino, M., \& Monda, B. (2012). The impact of corporate governance on the market value of financial institutions: Empirical evidence from Italy. Banks and Bank Systems, 7(2).

Byrd, E. T., Cardenas, D. A., \& Dregalla, S. E. (2009). Differences in Stakeholder Attitudes of Tourism development and the natural Environment. The University of North Carolina e-Review of Tourism Research (eRTR), 7(2), 39-51.

Cahan, S. F., Chen, C., Chen, L., \& Nguyen, N. H. (2015). Corporate social responsibility and media coverage. Journal of Banking \& Finance, 59, 409-422. https://doi.org/10.1016/j.jbankfin.2015.07.004

Cai, L., \& He, C. (2014). Corporate environmental responsibility and equity prices. Journal of Business Ethics, 125, 617-635. https://doi.org/10.1007/s10551-013-1935-4 
Callan, S., \& Thomas, J. (2009). Corporate financial performance and corporate social performance: An update and reinvestigation. Corporate Social Responsibility and Environmental Management, 16(2), 61-78. https://doi.org/10.1002/csr.182

Carroll, A. B., \& Buchholtz, A. K. (2012). Business and society: Ethics and stakeholder management ( $8^{\text {th }}$ ed.). South-Western Cengage Learning.

Carroll, A. B. (1991). The Pyramid of corporate social responsibility: Toward the moral management of organizational stakeholders. Business Horizons, 34(4), 39-48. https://doi.org/10.1016/0007-6813(91)90005-G

Casado-Díaz, J. M., \& Simón, H. (2016). Wage differences in the hospitality sector. Tourism Management, 52, 96-109. https://doi.org/10.1016/j.tourman.2015.06.015

Cheung, Y.-L., Jiang, P., Limpaphayom, P., \& Lu, T. (2008). Does corporate governance matter in China?. China Economic Review, 19(3), 460-479. https://doi.org/10.1016/j.chieco.2008.01.002

Claessens, S., \& Yurtoglu, B. B. (2013). Corporate governance in emerging markets: A survey. Emerging Markets Review, 15, 1-33. https://doi.org/10.1016/j.ememar.2012.03.002

Clark, G. L., \& Viehs, M. (2014). The implications of corporate social responsibility for investors: An overview and evaluation of the existing CSR literature. https://doi.org/10.2139/ssrn.2481877

Davis, T., \& Cahill, S. (2000). Environmental implications of the tourism industry (Discussion paper 00-14). Resources for the Future.

De Klerk, M., de Villiers, C., \& van Staden, C. (2015). The influence of corporate social responsibility disclosure on share prices: Evidence from the United Kingdom. Pacific Accounting Review, 27(2), 208-228. https://doi.org/10.1108/PAR-05-2013-0047

Derwall, J., Koedijk, K., \& Ter Horst, J. (2010). A tale of values-driven and profit-seeking social investors. https://doi.org/10.2139/ssrn.1641131

Eccles, R. G., Ioannou, I., \& Serafeim, G. (2014). The impact of corporate sustainability on organizational processes and performance. Management Science, 60(11), 2835-2857. https://doi.org/10.1287/mnsc.2014.1984

Elzahar, H., Hussainey, K., Mazzi, F., \& Tsalavoutas, I. (2015). Economic consequences of key performance indicators' disclosure quality. International Review of Financial Analysis, 39, 96-112. https://doi.org/10.1016/j.irfa.2015.03.005

Erickson, T., \& Whited, T. M. (2012). Treating Measurement Error in Tobin's q. The Review of Financial Studies, 25(4), 1286-1329. https://doi.org/10.1093/rfs/hhr120

Fatemi, A. M., Fooladi, I. J, \& Tehranian, H. (2015). Valuation effects of corporate social responsibility. Journal of Banking \& Finance, 59, 182-192. https://doi.org/10.1016/j.jbankfin.2015.04.028

Fisher-Vanden, K., \& Thorburn, K. S. (2011). Voluntary corporate environmental initiatives and shareholder wealth. Journal of Environmental Economics and Management, 62(3), 430-445. https://doi.org/10.1016/j.jeem.2011.04.003

Flammer, C. (2015). Does product market competition foster corporate social responsibility? Evidence from trade liberalization. Strategic Management Journal, 36(10), 1469-1485. https://doi.org/10.1002/smj.2307

Freeman, R. E. (1984). Strategic management: A stakeholder approach. Boston: Pitman Publishing Inc. (Reprinted in 2010 by Cambridge University Press).

Friede, G., Busch, T., \& Bassen, A. (2015). ESG and financial performance: aggregated evidence from more than 2000 empirical studies. Journal of Sustainable Finance and Investment, 5(4), 210-233. https://doi.org/10.1080/20430795.2015.1118917

Friedman, M. (1970). The social responsibility of business is to increase its profits. New York Times Magazine, 32(33), 122-126.

Galbreath, J. (2013). ESG in focus: The Australian evidence. Journal of Business Ethics, 118(3), 529-541. https://doi.org/10.1007/s10551-012-1607-9 
Galema, R., Plantinga, A., \& Scholtens, B. (2008). The stocks at stake: return and risk in socially responsible investment. Journal of Banking and Finance, 32(12), 2646-2654. https://doi.org/10.1016/j.jbankfin.2008.06.002

Giese, G., Lee, L.-E., Melas, D., Nagy, Z., \& Nishikawa, L. (2017). Foundations of ESG investing. Part 1: How ESG affects equity valuation, risk and performance. MSCI Research Insight.

Giese, G., Lee, L.-E., Melas, D., Nagy, Z., \& Nishikawa, L. (2018). Foundations of ESG investing Part 3: Integrating ESG into Benchmarks. MSCI Research Insight.

Gompers, P., Ishii, J., \& Metrick, A. (2003). Corporate governance and equity prices. The Quarterly Journal of Economics, 118(1), 107-156. https://doi.org/10.1162/00335530360535162

Greening, D. W., \& Turban, D. B. (2000). Corporate social performance as a competitive advantage in attracting a quality workforce. Business \& Society, 39(3), 254-280. https://doi.org/10.1177/000765030003900302

Hassel, L., Nilsson, H., \& Nyquist, S. (2005). The value relevance of environmental performance. European Accounting Review, 14(1), 41-61. https://doi.org/10.1080/0963818042000279722

Hassel, L., \& Semenova, N. (2013). The added value of ESG/SRI on company and portfolio levels What can we learn from research?, In CSR and beyond - A Nordic perspective (pp.137-163). Cappelen Damm Akademisk.

Hillman, A. J., \& Keim, G. D. (2001). Shareholder value, stakeholder management, and social issues: What's the bottom line?. Strategic Management Journal, 22(2), 125-139. https://doi.org/10.1002/1097-0266(200101)22:2<125::AID-SMJ150>3.0.CO;2-H

Hong, H., \& Kacperczyk, M. (2009). The price of sin: The effects of social norms on markets. Journal of Financial Economics, 93(1), 15-36. https://doi.org/10.1016/j.jfineco.2008.09.001

Horvathova, E. (2010). Does environmental performance affect financial performance? A meta-analysis. Ecological Economics, 70(1), 52-59. https://doi.org/10.1016/j.ecolecon.2010.04.004

Hsu, K. (2012). The advertising effects of corporate social responsibility on corporate reputation and brand equity: Evidence from the life insurance industry in Taiwan. Journal of Business Ethics, 109(2), 189-201. https://doi.org/10.1007/s10551-011-1118-0

Jacobs, B. W., Singhal, V. R., \& Subramanian, R. (2010). An empirical investigation of environmental performance and the market value of the firm. Journal of Operations Management, 28(5), 430-441. https://doi.org/10.1016/j.jom.2010.01.001

Johnson, S. C. (1994). Travel services - industry overview (pp. 41-42). U.S. Department of Commerce, U.S. Industrial Outlook. https://doi.org/10.1016/0029-6554(94)90037-X

Kaspereit, T., \& Lopatta, K. (2013). The value relevance of SAM's corporate sustainability ranking and GRI sustainability reporting in the European stock markets (ZenTra Working Paper in Transnational Studies, 19). https://doi.org/10.2139/ssrn.2344631

Krce Miočić, B., Razovič, M., \& Klarin, T. (2016). Management of sustainable tourism destination through stakeholder cooperation. Management, 21(2), 99-120.

Krüger, P. (2015). Climate change and firm valuation: Evidence from a quasi-natural experiment (Research Paper Series No. 15-40, 59 p.). Swiss Finance Institute. https://doi.org/10.2139/ssrn.2565523

Lee, S.-C., Chen, J.-L., \& Tsa, M.-S. (2014). An empirical investigation of the Ohlson model - A panel cointegration approach. Australasian Accounting, Business and Finance Journal, 8(2), 35-51. https://doi.org/10.14453/aabf.v8i2.4

Liu, X., \& Zhang, C. (2017). Corporate governance, social responsibility information disclosure, and enterprise value in China. Journal of Cleaner Production, 142(Part 2), 1075-1084. https://doi.org/10.1016/j.jclepro.2016.09.102

Lo, K., \& Lys, T. (2000). The Ohlson model: Contribution to valuation theory, limitations, and empirical applications. Journal of Accounting, Auditing and Finance, 15(3), 337-367.

https://doi.org/10.1177/0148558X0001500311 
Lourenço, I. C., Branco, M. C., Curto, J. D., \& Eugenio, T. (2012). How does the market value corporate sustainability performance?. Journal of Business Ethics, 108(4), 417-428. https://doi.org/10.1007/s10551-011-1102-8

Lyon, T., Lu, Y., Shi, X., \& Yin, Q. (2013). How do investors respond to green company awards in China?. Ecological Economics, 94, 1-8. https://doi.org/10.1016/j.ecolecon.2013.06.020

Mackey, A., Mackey, T. B., \& Barney, J. B. (2007). Corporate social responsibility and firm performance: Investor preferences and corporate strategies. Academy of Management Review, 32(3), 817-835. https://doi.org/10.5465/amr.2007.25275676

Malik, M. (2015). Value-enhancing capabilities of CSR: A brief review of contemporary literature. Journal of Business Ethics, 127(2), 419-438. https://doi.org/10.1007/s10551-014-2051-9

Margolis, J. D., Elfenbein, H. A., \& Walsh, J. P. (2009). Does it pay to be good and does it matter? A meta-analysis of the relationship between corporate social and financial performance. https://doi.org/10.2139/ssrn.1866371

McIntosh, R. W., \& Goeldner, C. R. (1990). Tourism: principles, practices, philosophies (p. 16). New York: John Wiley and Sons.

McWilliams, A., \& Sigel, D. (2000). Corporate social responsibility and financial performance: Correlation or misspecification?. Strategic Management Journal, 21(5), 603-609. https://doi.org/10.1002/(SICI)1097-0266(200005)21:5<603::AID-SMJ101>3.0.CO;2-3

McWilliams, A., \& Sigel, D. (2001). Corporate social responsibility: A theory of the firm perspective. The Academy of Management Review, 26(1), 117-127. https://doi.org/10.5465/amr.2001.4011987

Miralles-Quirós, M. M., Miralles-Quirós, J. L., \& Valente Gonçalves, L. M. (2018). The value relevance of environmental, social, and governance performance: The Brazilian case. Sustainability, 10(3), 574. https://doi.org/10.3390/su10030574

Mitchell, R., Agle, B., \& Wood, D. (1997). Toward a theory of stakeholder identification and salience: Defining the principle of who and what really counts. The Academy of Management Review, 22(4), 853-886. https://doi.org/10.5465/amr.1997.9711022105

Moneva, J. M., \& Cuellar, B. (2009). The value relevance of financial and non-financial environmental reporting. Environmental and Resource Economics, 44(3), 441-456. https://doi.org/10.1007/s10640-009-9294-4

Moon, J. (2007). The contribution of corporate social responsibility to sustainable development. Sustainable Development, 15(5), 296-306. https://doi.org/10.1002/sd.346

Ohlson, J. A. (1995). Earnings, book value, and dividends in equity valuation. Contemporary Accounting Research, 11(2), 661-687. https://doi.org/10.1111/j.1911-3846.1995.tb00461.x

Orlitzky, M., Schmidt, F. L., \& Rynes, S. L. (2003). Corporate social and financial performance: A meta-analysis. Organization Studies, 24(3), 403-441. https://doi.org/10.1177/0170840603024003910

Palmer, K., Oates, W. E., \& Portey, P. R. (1995). Tightening environmental standards: the benefit-cost or the no-cost paradigm?. Journal of Economic Perspectives, 9(4), 119-132. https://doi.org/10.1257/jep.9.4.119

Ping, Z., \& Cheng Wui Wing, A. (2011). Corporate governance: A summary review on different theory approaches. International Research Journal of Finance \& Economics, 68, 7-13.

Porter, M. E., \& Kramer, M. R. (2011). Creating shared value. Harvard Business Review, 89, 62-77.

Power, T. M. (1996). Lost landscapes and failed economies: The search for a value of place (p. 215). Washington, DC: Island Press.

Radhouane, I., Nekhili, M., Nagati, H., \& Paché, G. (2018). The impact of corporate environmental reporting on customer-related performance and market value. Management Decision, 56(7), 16301659. https://doi.org/10.1108/MD-03-2017-0272

Renneboog, L., Horst, J. T., \& Zhang, C. (2008b). Socially responsible investments: Institutional aspects, performance, and investor behaviour. Journal of Banking \& Finance, 32(9), 1723-1742.

https://doi.org/10.1016/j.jbankfin.2007.12.039 
Renneboog, L., Horst, J. T., \& Zhang, C. (2008a). The price of ethics and stakeholder governance: The performance of socially responsible mutual funds. Journal of Corporate Finance, 14(3), 302-322. https://doi.org/10.1016/j.jcorpfin.2008.03.009

Sanchez-Ollero, J. L., Campos-Soria, J. A., \& Garcia-Pozo, A. (2014). The labor market in the Spanish hospitality industry: An overview from a gender perspective. Revista Turismo y Desenvolvimiento, $21 / 22$.

Semenova, N., Hassel, L., \& Nilsson, F. (2010). The value relevance of environmental and social performance: Evidence from Swedish SIX 300 companies. The Finnish Journal of Business Economics, 3/10, 265-292.

Sen, S., \& Bhattacharya, C. B. (2001). Does doing good always lead to doing better? Consumer reactions to corporate social responsibility. Journal of Marketing Research, 38(2), 225-243. https://doi.org/10.1509/jmkr.38.2.225.18838

Shank, T. M., Manullang, D. K., \& Hill, R. P. (2005). Is it better to be naughty or nice?. The Journal of Investing, 14(3), 82-87. https://doi.org/10.3905/joi.2005.580553

Sikken, B. J. (2011). Accelerating the transition towards sustainable investing - strategic options for investors, corporations, and other key stakeholders (World Economic Forum Paper). https://doi.org/10.2139/ssrn.1891834

Singh, S., Tabassum, N., Darwish, T. K., \& Batsakis, G. (2018). Corporate governance and Tobin's Q as a measure of organizational performance. British Journal of Management, 29(1), 171-190. https://doi.org/10.1111/1467-8551.12237

Sparkes, R. \& Cowton, C. J. (2004). The maturing of socially responsible investment: A review of the developing link with corporate social responsibility. Journal of Business Ethics, 52(1), 45-57. https://doi.org/10.1023/B:BUSI.0000033106.43260.99

Statman, M., \& Glushkov, D. (2009). The wages of social responsibility. Financial Analysts Journal, 65(4), 33-46. https://doi.org/10.2469/faj.v65.n4.5

Statman, M. (2000). Socially responsible mutual funds. Financial Analysts Journal, 65(3), 30-39. https://doi.org/10.2469/faj.v56.n3.2358

Waddock, S., Bodwell, C., \& Graves, S. B. (2002). Responsibility: The new business imperative. Academy of Management Executive, 16(2), 132-148. https://doi.org/10.5465/ame.2002.7173581

Waddock, S., \& Graves, S. B. (1997). The corporate social performance - Financial performance link. Strategic Management Journal, 18(4), 303-319. https://doi.org/10.1002/(SICI)1097-0266(199704)18:4<303::AID-SMJ869>3.0.CO;2-G

Walsh, G., \& Bartikowski B. (2013). Exploring corporate ability and social responsibility associations as antecedents of customer satisfaction cross-culturally. Journal of Business Research, 66(8), 989-995. https://doi.org/10.1016/j.jbusres.2011.12.022

Wang, M.-C. (2015). Value relevance of Tobin's Q and corporate governance for the Taiwanese tourism industry. Journal of Business Ethics, 130(1), 223-230. https://doi.org/10.1007/s10551-014-2339-9

Welford, R. J. (2004). Corporate social responsibility in Europe and Asia: Critical elements and best practice. Journal of Corporate Citizenship, 2004(13), 31-47. https://doi.org/10.9774/GLEAF.4700.2004.sp.00007

World Travel and Tourism Council (WTTC). (2018, September). Travel \& tourism economic Impact 2018. Retrieved from www.wttc.org

World Travel and Tourism Council (WTTC). (2019, January). Understanding the critical issues for the future of travel and tourism, 2017. Retrieved from www.wttc.org

Xie, Y. (2014). The effects of corporate ability and corporate social responsibility on winning customer support: An integrative examination of the roles of satisfaction, trust and identification. Global Economic Review, 43(1), 73-92. https://doi.org/10.1080/1226508X.2014.884050

Zivin, J. G., \& Small, A. A. (2005). Modigliani-Miller theory of altruistic corporate social responsibility. The B.E. Journal of Economic Analysis \& Policy, 5(1), 1-19. https://doi.org/10.1515/1538-0653.1369 